\title{
Analisis Media Sosial Twitter Terhadap Topik Vaksinasi Covid-19
}

\author{
Rosita Yanuarti \\ Universitas Muhammadiyah Jember \\ Email: rosita.yanuarti@unmuhjember.ac.id
}

(Naskah masuk: 6 Juli 2021, diterima 28 Agustus 2021, diterbitkan: 31 Agustus 2021)

\begin{abstract}
ABSTRAK
Analisis media sosial khususnya pada Twitter merupakan implementasi pemrosesan teks secara eksplisit dengan menggunakan data cuitan pada media sosial Twitter untuk menghasilkan informasi. Teknik ini sangat efektif dalam memahami informasi-informasi yang terkait terhadap suatu topik tertentu yang sedang dibahas oleh pengguna Twitter. Analisis media sosial pada twitter yang dilakukan pada penelitian ini, bertujuan untuk mengekstrak dan menganalisis komentar publik atau tweets tentang topik-topik yang terkait pelaksanaan pemberian vaksinasi covid-19 di Indonesia. Komponen pengukuran yang dianalisis meliputi centrality untuk menunjukkan aktor sentral dalam media sosial, dan modularity untuk mendapatkan jumlah komunitas yang terbagi pada media sosial, dan analisis konten yang menghasilkan frekuensi kata yang banyak muncul pada komentar user (tweets) tentang vaksinasi covid-19 di Indonesia yang direpresentasikan dengan word clouds. Adapun tahapan-tahapan pada analisis media sosial dimulai dengan definisi permasalahan, pengumpulan data, pembersihan data, analisis, visualisasi, dan kesimpulan. Gephi digunakan sebagai tool untuk menganalisis pengukuran centrality dan modularity yang dihasilkan dari data tweet. Hasil dari penelitian ini menunjukkan bahwa dari visualisasi analisis berupa graph tweets dihasilkan 185 nodes dan 101 edges, nilai modularity : 0.815, jumlah komunitas sebanyak 20 grup, dan Influencial Users adalah 'tvOneNews', 'ryolandafit', 'renatarecreio', 'detikcom'.
\end{abstract}

Kata kunci: Analisis Media Sosial, Centrality, Modularity, Word Cloud

\begin{abstract}
Social media analysis, especially on Twitter, is an explicit implementation of text processing, using tweets data on Twitter social media to generate information. This technique is very effective in understanding information related to a particular topic that being discussed by Twitter users. The analysis of social media on Twitter that conducted in this study, aims to extract and analyze public comments or tweets based on topics that related to the implementation of the Covid-19 vaccination in Indonesia. This research analyzed three type components such as Centrality to identify the central actor in social media, Modularity to get the number of communities on social media, and content analysis to get the information about trend based on the frequency of words that appear in user comments (tweets) that represented by word clouds. The stages in social media analysis begin with problem definition, data collection, data cleaning, analysis, visualization, and conclusions. Gephi is used as a tool to analyze the measurement of centrality and modularity that generated from tweet data. The results of this study generate 185 nodes and 101 edges from graph tweets, the value of modularity is 0.815 , the number of communities is 20 groups, and show the influencial users are 'tvOneNews', 'ryolandafit', 'renatarecreio', 'detikcom'.
\end{abstract}

Keywords: Social Media Analysis, Centrality, Modularity, Word Cloud 


\section{PENDAHULUAN}

Pertumbuhan data yang meningkat setiap tahunnya, $80 \%$ terdiri dari data yang bersifat unstructured data, khususnya dalam bentuk teks. (Berger, 2016). Data unstructured tersebut banyak dihasilkan dari media sosial. Twitter merupakan media sosial yang populer di Internet. Melalui twitter, pengguna dapat membagikan opini, acara, dan berinteraksi dengan pengguna lain. Pertumbuhan penggunaan media sosial membuka peluang baru untuk menganalisis beberapa aspek, dan pola dalam komunikasi. Misalnya, data media sosial dapat dianalisis untuk mendapatkan wawasan tentang masalah-masalah, tren, aktor berpengaruh, dan jenis informasi lainnya. (Stieglitz, 2017). Analisis media sosial khususnya pada Twitter merupakan salah satu implementasi dari text mining dengan memanfaatkan cuitan (tweet) pada Twitter. Text mining yang dapat bekerja dalam komputer dengan tujuan mengolah informasi lama secara eksplisit sehingga menghasilkan temuan informasi baru (Syarifuddin, 2020). Oleh karena itu, teknik ini sangat efektif dalam memahami informasi-informasi yang terkait terhadap suatu topik tertentu yang sedang dibahas oleh pengguna Twitter. Meskipun twitter belum dapat dikatakan sebagai percakapan publik yang komprehensif, namun twitter dapat membantu memberikan wawasan tentang tren populer termasuk momen yang penting seperti pemberian vaksin covid-19 di Indonesia.

Pelaksanaan vaksinasi Covid-19 di Indonesia banyak mengalami kendala di masyarakat. Sebagian masyarakat mendukung program vaksinasi Covid-19 ini, namun tidak sedikit yang meragukan efektifitas dan keampuhan vaksin Covid19. Beberapa di antara yang meragukan keefektifan dan keampuhan vaksin Covid19, bahkan menolak untuk diberi vaksin. (Humas Litbangkes, 2021). Saat ini pelaksanaan vaksinasi covid-19 di Indonesia baru mencapai $20 \%$ dari total sasaran yang divaksin. Untuk mencapai kekebalan imunitas dengan syarat hingga mencapai $70 \%$ penduduk telah divaksin, membutuhkan dukungan dari semua pihak. Penggunaan media sosial memberikan peran yang sangat besar dalam sosialisasi pelaksanaan vaksinasi covid-19 di Indonesia. Berdasarkan data dari Global Digital Statistic "Digital, Social \& Mobile in 2019", pada tahun 2019 jumlah pengguna media sosial di Indonesia yaitu berjumlah lebih dari 150 juta pengguna. Salah satu media sosial yang paling banyak digunakan oleh masyarakat Indonesia adalah media sosial twitter, yang mencakup lebih dari $52 \%$ dari total pengguna media sosial di Indonesia. Hal tersebut menunjukkan adanya peluang sumber data yang sangat besar yang dapat dimanfaatkan untuk menghasilkan suatu knowledge yang bermanfaat. (Rachman dan Pramana, 2020). Oleh karena itu, pentingnya diperlukan suatu teknik untuk mengekstrak dan menganalisis sumber data yang sangat besar pada suatu topik pelaksanaan vaksinasi covid-19 di Indonesia. Guna melihat bagaimana informasi yang dihasilkan tentang pembicaraan publik tentang pelaksanaan vaksinasi di Indonesia.

Analisis media sosial pada twitter yang dilakukan pada penelitian ini, bertujuan untuk mengekstrak dan menganalisis informasi dari komentar publik atau tweets tentang topik-topik yang terkait pelaksanaan pemberian vaksinasi covid-19 di Indonesia menggunakan Python dan Gephi.

Penelitian terkait yang telah dilakukan sebelumnya adalah Mining Social Media 
and DBpedia Data Using Gephi and $R$ oleh (Hussain dkk, 2018). Analisis media sosial yang dilakukan dengan meenggunakan tool Gephi dan R. Data media sosial yang digunakan adalah terdiri dari dua set data, yaitu data yang terdiri dari atribut tweetid, creation date and time, text, URL, latitude, longitude, retweets, favorites, hashtag, source device, emoji, dan data cuitan (tweets) dari Twitter tentang Imigrasi di Kanada, Facebook, dan DBpedia dengan menghitung nilai average degree, average weighted degree, modularity, network diameter, dan average path length. Hasil pengukuran dari penelitian ini adalah nilai average degree untuk dataset dari DBPedia, Facebook dan Twitter adalah 1,066, 5,946, dan 2,117. Untuk nilai average weighted degree masing-masing dataset 1,17, 5,496, dan 2,117. Network diameter dari masing-masing dataset 2, 8, dan 5. Nilai modularity 0,657 untuk dataset dbpedia, 0,588 untuk Facebook, dan 0,46 untuk Twitter, dan nilai average path length dari dataset dbpedia adalah 1,001, dan 3,221 untuk dataset Facebook, dan 1,425 untuk dataset Twitter. Dari penelitian ini disimpulkan bahwa tools Gephi dan R Studio merupakan tool yang sangat kuat untuk penambangan dan eksplorasi pada big data.

Penelitian terkait analisis media sosial lainnya adalah $A$ Social Network Analysis of Tweets Related to Masks during the COVID-19 Pandemic oleh (Ahmed dkk, 2020). Penelitian ini difokuskan untuk menganalisis konten dari Twitter terkait masker selama pandemi COVID-19. Tweets diekstrak dan dianalisis menggunakan software analisis media sosial yaitu NodeXL. NodeXL (Social Media Research Foundation, California, $C A$, USA) digunakan untuk mengidentifikasi pengguna yang berpengaruh berdasarkan sentralitas dan digunakan untuk mengidentifikasi tagar dan konten utama.

\section{A. Analisis Media Sosial}

Analisis media sosial merupakan salah satu aplikasi dari text mining. Text mining atau dapat disebut dengan text analytics adalah sebuah metodologi dan pemrosesan dari data tekstual yang dilakukan untuk menghasilkan (generate) informasi dan wawasan yang berkualitas dan dapat ditindaklanjuti (actionable insights). (Sarkar, 2016).

Menurut Gartner Research, analisis media sosial adalah monitoring, analisis, mengukur, dan menafsirkan interaksi digital dan hubungan orang, topik, ide dan konten lainnya yang terjadi melalui media sosial. Analisis media sosial mencakup analisis sentimen, pemrosesan bahasa alami (natural language processing), analisis social networking (influencer identification, profiling and scoring), dan teknik yang lebih kompleks seperti analisis teks, pemodelan dan rekomendasi prediktif, serta identifikasi dan klasifikasi secara otomatis tentang topik/subjek, orang, atau konten.

Dalam penelitian (Sebei dkk, 2018), analitik media sosial didefinisikan sebagai bidang penelitian interdisipliner yang muncul yang bertujuan untuk menggabungkan, memperluas, dan mengadaptasi metode untuk analisis data media sosial. Analitik media sosial juga dianggap sebagai alat dan kerangka kerja untuk mengumpulkan, memantau, menganalisis, meringkas, dan memvisualisasikan data media sosial, biasanya didorong oleh persyaratan khusus dari tujuan atau target dari aplikasi.

Data media sosial memiliki volume yang tinggi, kecepatan yang tinggi, dan sangat beragam, hal ini menjadi keuntungan dalam hal pengetahuan yang dikandungnya, namun, menganalisis dan menafsirkan pengetahuan tersebut 
memiliki beberapa tantangan. Data media sosial berukuran besar dan dihasilkan dengan cepat, maka menangkap dan menganalisis jutaan tweet / komentar yang muncul setiap detik adalah tantangan nyata. Disamping itu, pengguna media sosial dan konten yang dihasilkan sangat beragam, multibahasa, dan bervariasi. Tweet atau mention dari pengguna media sosial yang berpengaruh lebih penting daripada tweet dari pengguna yang tidak berpengaruh. Dari segi sifat datanya, sifat data media sosial yang noise dan beragam, memisahkan konten penting dari noise merupakan hal yang menantang dan memakan waktu. Data media sosial bersifat tidak terstruktur dan terdiri dari teks, grafik, actions, dan hubungan. Teks pendek media sosial, seperti tweet dan komentar, memiliki struktur gramatikal yang meragukan, dan sarat dengan singkatan, akronim, dan emoticon (simbol atau kombinasi simbol yang digunakan untuk menyampaikan ekspresi emosional dalam pesan teks). (Khan, 2015).

Proses mengekstrak informasi penting dari sekumpulan data teks yang besar cukup rumit dan sulit terutama untuk data Twitter. Hal ini disebabkan beberapa faktor, antara lain: (1) Keragaman data dari segi bahasa, kata-kata yang pendek, emoticon. (2) Kompleksitas bahasa alami. (3) Terdapat banyak cara untuk merepresentasikan konsep yang sama, dan mengarah pada ambiguitas. (4) Data memiliki dimensi tinggi. (5) Sumber data teks tidak terstruktur dan heterogen. (6) Tweet biasanya tidak terstruktur secara tata bahasa dibandingkan dengan teks dokumen biasa. (Dutta dkk, 2018)

\section{B. Python}

Python adalah salah satu bahasa pemrograman paling umum pada bidang data science, selain bahasa pemrograman $R$. Keuntungan utama Python adalah fleksibilitas dan kesederhanaannya. Oleh karena itu, membuat analisis dan manipulasi data menjadi mudah karena didukung dengan banyak library atau paket dalam data science. (Chatterjee, 2017). Library Python yang paling populer untuk data science adalah NumPy, SciPy, Pandas, dan Scikit-Learn. Pada Python juga terdapat library yang mendukung yang berkaitan dengan pemrosesan bahasa alami yaitu Natural Language Toolkit (NLTK). Paket-paket dalam NLTK meliputi library untuk pemrosesan teks untuk klasifikasi, tokenisasi, stemming, tagging, parsing, dan penalaran semantik.

\section{Gephi}

Gephi adalah perangkat lunak yang bersifat open source untuk mengimpor, memvisualisasikan, mengatur spasial, memfilter, memanipulasi, dan mengekspor semua jenis jaringan grafik dan analisis jaringan dan menggunakan mesin rendering 3D untuk menampilkan jaringan besar secara real-time dan untuk mempercepat eksplorasi. Gephi memiliki arsitektur yang fleksibel dan multi-task yang memungkinkan bekerja dengan kumpulan data yang kompleks dan menghasilkan hasil visual yang bernilai. (Hussain, 2018).

\section{METODE PENELITIAN}

Pada penelitian ini, metode penelitian terdiri dari tahapan definisi permasalahan, pengumpulan data, pembersihan data, analisis, visualisasi, dan kesimpulan. Tahapan-tahapan analisis media sosial tersebut ditunjukkan pada Gambar 1. 


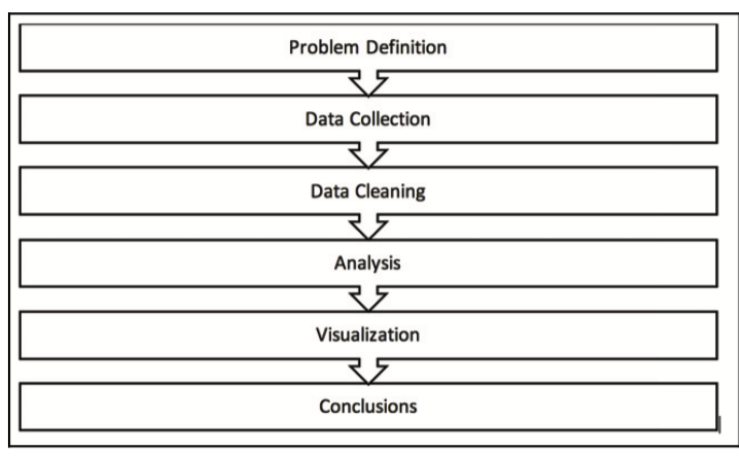

Gambar 1. Tahapan analisis media sosial (Chatterjee, 2017)

\section{A. Definisi permasalahan}

Memahami dan mendefinisikan masalah sangat penting untuk memilih sumber data yang tepat dan metode analisis. Tahapan ini dapat membantu untuk menemukan jenis informasi dan kesimpulan yang diperoleh dari data dan apa yang tidak mungkin diperoleh.

\section{B. Pengumpulan Data}

Banyak platform media sosial memungkinkan pengguna untuk mengumpulkan banyak informasi secara otomatis melalui API (Antarmuka Pemrograman Aplikasi), yang merupakan cara termudah untuk mengumpulkan data.

\section{Pembersihan Data}

Pada media sosial, data berbentuk tidak terstruktur yang terdiri dari teks, gambar, video, atau suara. Dan data yang tidak terstruktur tersebut lebih banyak terdiri dari teks. Maka, data teks tersebut harus dibersihkan dan dinormalisasi. Preprocessing adalah salah satu bagian terpenting dari proses analisis. Preprocessing merupakan bagian dari tahapan pembersihan data. Tujuannya adalah memformat ulang data yang tidak terstruktur menjadi seragam, bentuk standar. Karakter, kata, dan kalimat yang diidentifikasi pada tahap ini adalah unit dasar yang diteruskan ke tahap pemrosesan lebih lanjut. Kualitas dari preprocessing sangat mempengaruhi hasil akhir pada keseluruhan proses. Adapun beberapa tahapan proses dari pembersihan teks sederhana seperti menghilangkan spasi, tanda baca, tag HTML dan karakter khusus hingga teknik normalisasi yang lebih canggih seperti tokenisasi, stemming, atau lemmatisasi.

\section{Analisis}

Tahapan ini bertujuan untuk memilih jenis analisis dan struktur data yang sesuai. Proses analisis yang bertujuan untuk memahami arti dari suatu percakapan, maka membutuhkan daftar verbatim sederhana (data tekstual), dan untuk melakukan analisis pada variabel yang berbeda, seperti jumlah like, tanggal, jumlah share, dan sebagainya. Maka, data harus digabungkan dalam suatu struktur kerangka data, di mana setiap baris berhubungan dengan data yang di observasi dan setiap kolom berhubungan dengan variabel. Selanjutnya proses analisis berkaitan juga pada metode yang digunakan dalam mengolah data.

\section{E. Visualisasi}

Tahapan selanjutnya adalah bagaimana mengkomunikasikan hasil analitis, dan mempresentasikan secara visual. Visualisasi pada dasarnya menyajikan hasil yang diperoleh dengan cara yang sederhana dan lebih cepat. Misalnya, melihat grafik dan mengidentifikasi tren dapat dilakukan dengan cepat. Word cloud salah satu teknik visualisasi yang menunjukkan hubungan antara jumlah kata dengan memperbesar kata yang lebih sering digunakan dengan cepat. $\mathrm{Hal}$ ini dikarenakan, kata-kata yang lebih besar dan ditampilkan dengan lebih mencolok, dan kata-kata tersebut dengan cepat menarik perhatian pembaca. Terlebih lagi untuk menarik kesimpulan tentang penggunaan satu kata dengan kata lainnya 
dapat dilakukan dengan pendekatan frekuensi frase kata (dua atau lebih kata yang digunakan bersamaan).

\section{F. Kesimpulan}

Menarik kesimpulan yang diperoleh berdasarkan keluaran dari model atau hasil dari visualisasi data. Data dan keluaran dapat disajikan dengan berbagai cara, mulai dari bagan, plot, dan diagram hingga bagan 2D yang lebih kompleks, hingga visualisasi multidimensi.

Pengukuran analisis media sosial yang digunakan pada penelitian ini antara lain : 1) Centrality, merupakan ukuran untuk memberikan indikasi kekuatan sosial suatu simpul dalam sebuah jejaring sosial berdasarkan seberapa baik mereka "terhubung" dalam jejaring sosial tersebut. Ukuran centrality ini berupaya untuk menunjukkan aktor "paling penting" atau bisa disebut dengan aktor sentral dalam suatu jejaring sosial. 2) Modularity, pengukuran ini digunakan untuk mendeteksi struktur komunitas. Modularity menunjukkan nilai kekuatan suatu jaringan terbagi menjadi klaster-klaster atau komunitas (grup), 3) analisis konten, mengidentifikasi kata yang paling sering muncul dalam topik terkait. Visualisasi analisis konten ini digambarkan dalam bentuk word clouds. Proses analisis ini menggunakan Gephi sebagai tool untuk menganalisis graph dari jaringan media sosial.

\section{HASIL DAN PEMBAHASAN}

\section{A. Analisis}

Analisis yang dilakukan pada penelitian ini terdiri dari beberapa tahapan dalam mengekstrak dan menganalisis komentar publik tentang pelaksanaan vaksin covid19 di Indonesia adalah sebagai berikut :
Pendefinisian masalah yaitu untuk mengekstrak dan menganalisis informasi media sosial tentang pelaksanaan vaksinasi covid-19 yang sedang berlangsung di Indonesia.

\section{Pengumpulan data}

Pengumpulan data berasal dari dataset tweets dari media sosial Twitter tentang topik vaksinasi covid-19 di Indonesia yang diambil pada tanggal 19 April 2021. Pengumpulan data dilakukan dengan memanfaatkan API Twitter untuk mendapatkan tweets dengan topik vaksin covid-19 di Indonesia.

\section{Pembersihan data}

Langkah selanjutnya adalah pembersihan data tweets. Tahapan pembersihan data meliputi pra-pemrosesan data yaitu tokenisasi, stopword removal, dan stemming. Tokenisasi adalah proses mengubah kalimat menjadi unit-unit yang disebut term atau token. Proses tokenisasi ditunjukkan pada Gambar 2. Selanjutnya proses stopword removal dilakukan untuk menghilangkan kata-kata umum yang tidak memiliki makna. Proses penghilangan stopword ditunjukkan pada Gambar 3. Sedangkan proses stemming dilakukan untuk mengubah kata berimbuhan menjadi kata dasar. Proses stemming ini ditunjukkan pada Gambar 4. Pembersihan data tweets dilakukan dengan menggunakan library nltk pada Python.

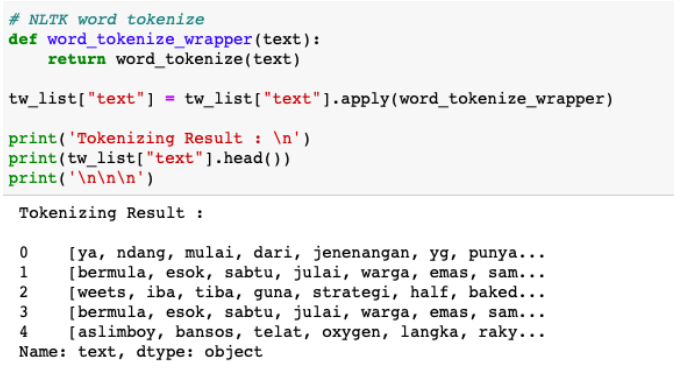

Gambar 2. Proses Tokenisasi

1. Definisi masalah 


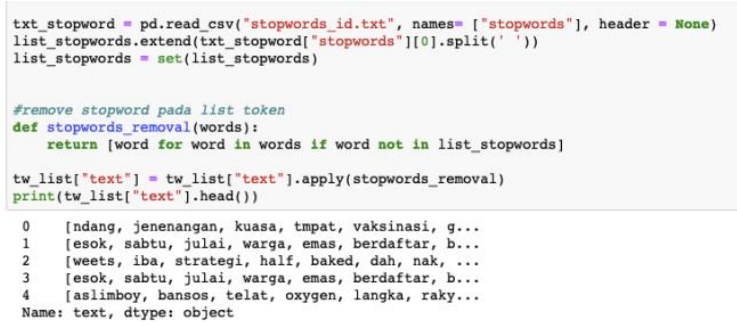

Gambar 3. Proses penghilangan stopword

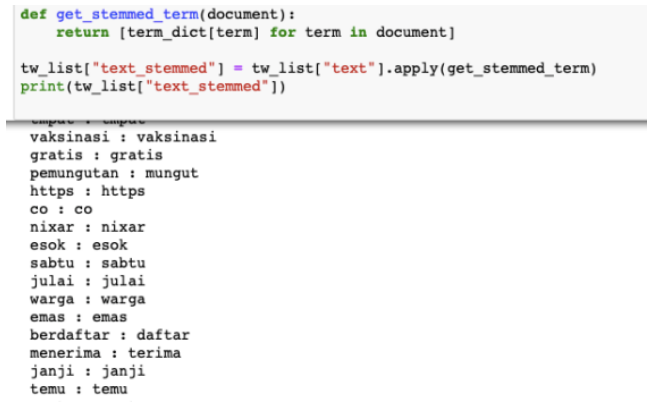

Gambar 4. Proses stemming

4. Analisis centrality, modularity dan konten tweets.

Setelah dilakukan pra-pemrosesan teks pada data tweets, maka dilanjutkan dengan proses analisis yaitu mengekstrak informasi yang ada pada tweets. Proses analisis yang dilakukan pada penelitian ini antara lain mengukur centrality, modularity, dan analisis konten berupa word cloud untuk memvisualisasikan kata-kata yang paling sering muncul dalam pembicaraan berkaitan dengan topik tertentu. Gambar 5 menunjukkan nodes dan edges dalam visualisasi graph pada Gephi.

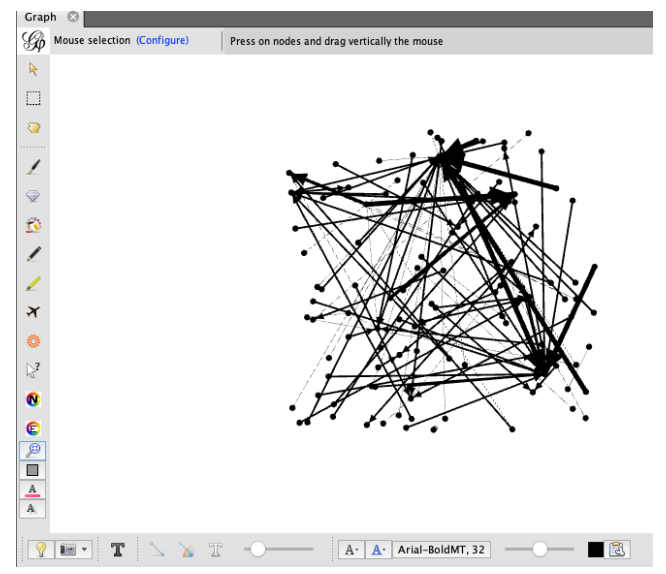

Gambar 5. Analisis graph pada Gephi

\section{B. Hasil Analisis}

Gambar 6 menunjukkan hasil visualisasi graph tweets untuk menunjukkan graph berdasarkan mentions. Berdasarkan graph tweets yang dihasilkan, terdapat 185 nodes dan 101 edges. Jumlah nodes ini menunjukkan banyaknya aktor yang terlibat, dan edges menunjukkan interaksi yang terjadi.

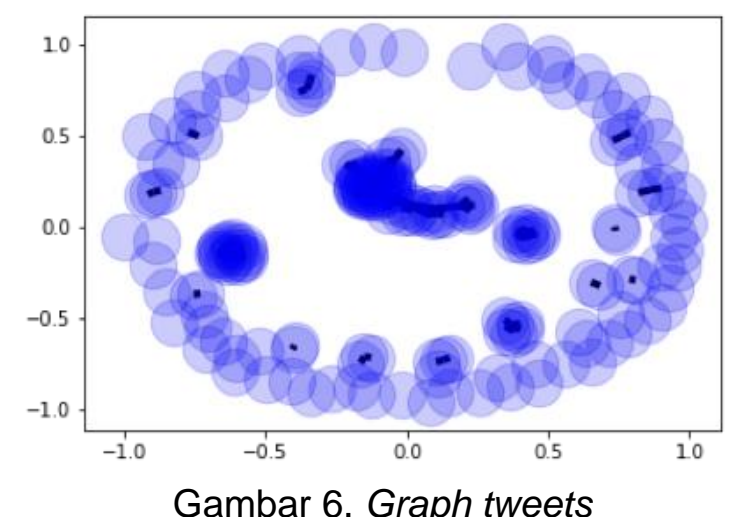

Pada pengukuran centrality terdapat pengguna-pengguna atau aktor-aktor yang paling berpengaruh antara lain tvOneNews, ryolandafit, renatarecreio, detikcom. Visualisasi centrality untuk menunjukkan pengguna yang berpengaruh ditunjukkan pada gambar 7 .

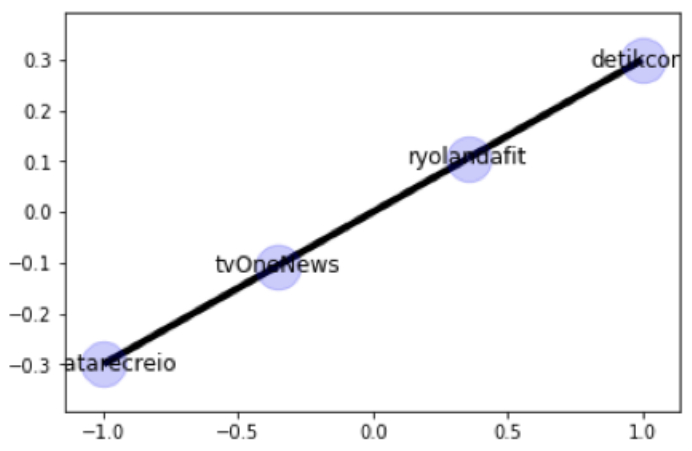

Gambar 7. Grafik influencial user

Dalam pengukuran modularity, terdapat 20 komunitas yang dihasilkan dari analisis graph yang ditunjukkan pada Gambar 8. Nilai average degree menunjukkan nilai rata-rata jumlah edges yang terhubung ke sebuah node yaitu hubungan yang dimiliki aktor, jika nilai average degree semakin tinggi maka semakin baik. Nilai diameter 
jaringan yang dihasilkan adalah 3 , nilai ini menunjukkan jarak maksimal antar nodes. Semakin kecil nilai diameter, maka akan semakin cepat informasi yang beredar. Nilai average path length 1.7795 juga menunjukkan kecepatan informasi yang ditunjukkan berdasarkan nilai jarak ratarata antar nodes. Hasil pengukuran ini dirangkum dalam tabel 1.

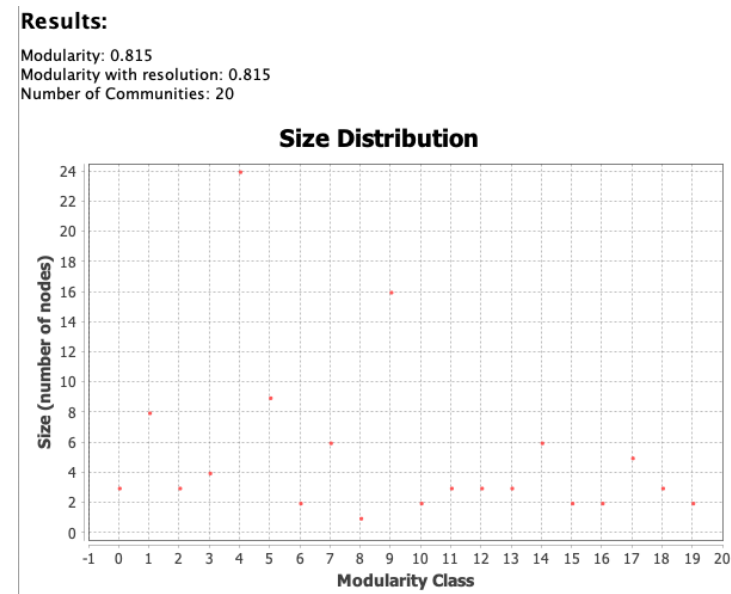

Gambar 8. Pengukuran modularity dengan Gephi

Sedangkan word cloud untuk menunjukkan hubungan antara jumlah kata dengan memperbesar kata yang lebih sering digunakan yang berkaitan dengan topik vaksinasi covid-19 di Indonesia, ditunjukkan pada gambar 9 .

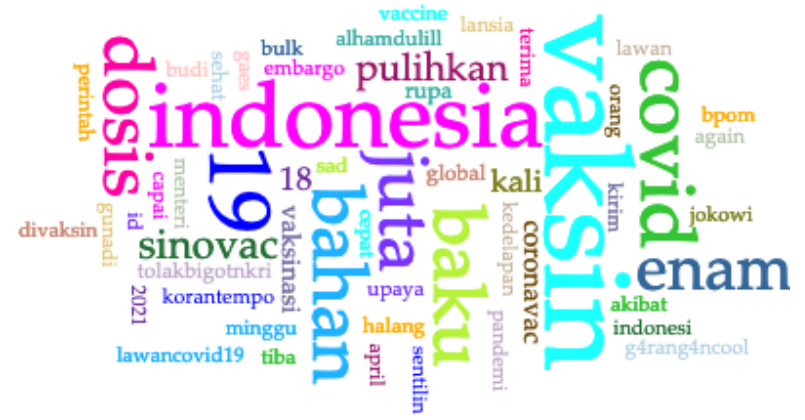

Gambar 9. Word cloud berkaitan topik vaksinasi

di Indonesia

Tabel 1. Hasil analisis media sosial twitter

\begin{tabular}{|c|c|c|}
\hline $\begin{array}{c}\text { Jenis } \\
\text { analisis }\end{array}$ & Parameter & Nilai \\
\hline \multirow[t]{5}{*}{ Centrality } & $\begin{array}{l}\text { Influencial } \\
\text { users }\end{array}$ & $\begin{array}{l}\text { tvOneNews, ryolandafit, } \\
\text { renatarecreio, detikcom }\end{array}$ \\
\hline & $\begin{array}{l}\text { Graph } \\
\text { tweets }\end{array}$ & 185 nodes dan 101 edges \\
\hline & $\begin{array}{c}\text { Average } \\
\text { Path Length }\end{array}$ & 1.7795 \\
\hline & Modularity & 0.815 \\
\hline & $\begin{array}{c}\text { Number of } \\
\text { Communities }\end{array}$ & 20 \\
\hline \multirow[t]{3}{*}{ Modularity } & $\begin{array}{l}\text { Average } \\
\text { Degree } \\
\text { Average }\end{array}$ & 0.963 \\
\hline & $\begin{array}{l}\text { Weighted } \\
\text { Degree }\end{array}$ & 1.720 \\
\hline & $\begin{array}{l}\text { Network } \\
\text { Diameter }\end{array}$ & 3 \\
\hline Tren & Word cloud & $\begin{array}{l}\text { vaksin, Indonesia, 19, } \\
\text { covid, juta, dosis, bahan, } \\
\text { baku, enam, sinovac, } \\
\text { pulihkan, kali, 18, } \\
\text { coronavac, vaksinasi, } \\
\text { rupa, global.tolakbigotnkri, } \\
\text { sehat, menteri. }\end{array}$ \\
\hline
\end{tabular}

\section{PENUTUP}

\section{KESIMPULAN}

Berdasarkan penelitian yang telah dilakukan dapat ditarik kesimpulan yaitu terdapat pengguna-pengguna atau aktoraktor yang paling berpengaruh antara lain tvOneNews, ryolandafit, renatarecreio, detikcom dan berdasarkan hasil analisis media sosial menunjukkan bahwa kecepatan informasi yang beredar dalam media sosial sangat cepat, hal ini ditunjukkan dengan nilai diameter jaringan dan nilai average path length pada hasil analisis yaitu 3 dan 1.7795, dikarenakan semakin kecil nilai diameter dan average path length, maka semakin cepat informasi yang beredar dalam jaringan media sosial tersebut. Sedangkan, untuk penyebaran informasi tidak luas, hal ini disebabkan oleh jumlah nodes dan edges yang dihasilkan sedikit, dan nilai average degree yang dihasilkan kecil yaitu 0.963 yang menunjukkan rata-rata hubungan yang dimiliki aktor. 
Ahmed, w., dkk., 2020. A Social Network Analysis of Tweets Related to Masks during the COVID-19 Pandemic. International Journal of Environmental Research and Public Health.

Humas Litbangkes. 2021. Tantangan Pelaksanaan Vaksinasi Covid-19 Di Indonesia. Badan Litbangkes Kementerian Kesehatan RI. https://www.litbang.kemkes.go.id/ta ntangan-pelaksanaan-vaksinasicovid-19-di-indonesia/. Diakses 26 Juli 2021.

Bratawisnu, M.K., dan Alamsyah, A. 2018. Social Network Analysis Untuk Analisa Interaksi User Di Media Sosial Mengenai Bisnis ECommerce (Studi Kasus: Lazada, Tokopedia, dan Elevenia). Jurnal Manajemen dan Bisnis Vol 2 No.2.

Ceder, N., 2018. The Quick Python Book 3rd Edition. Manning Publications

Chatterjee, S., Krystyanczuk, M. 2017. Python Social Media Analytics Analyze and visualize data from Twitter, Youtube, GitHub, and more. Packt Publishing.

Chaudhri, A, A. Dkk., 2021. Implementation Paper on Analyzing COVID-19 Vaccines on Twitter Dataset Using Tweepy and Text Blob.

Dutta, L., Maji, G., and Sen, S. 2018. A Study On Spatio Temporal Topical Analysis of Twitter Data. Springer.

Ganis, M., and Kohirkar, A., 2015. Social Media Analytics Techniques and Insights for Extracting Business Value Out of Social Media. IBM Press.

Hussain, S. dkk., 2018. Mining Social Media and DBpedia Data Using Gephi and R. Journal of Applied Computer Science \& Mathematics.
Igual, L., Segui, S. 2017. Introduction to Data Science. A Python Approach to Concepts, Techniques and Applications. Springer.

IT Gartner Glossary, Gartner. Social Analytics. Gartner IT Glossary. https://www.gartner.com/en/informa tion-technology/glossary/socialanalytics. Diakses 26 Juli 2021.

Khan, G.F. 2015. Seven Layers Of Social Media Analytics : Mining Business Insights From Social Media Text, Actions, Networks, Hyperlinks, Apps, Search Engine, and Location Data.

Kumar, S., Morstatter, F., dan Liu, H. 2014. Twitter Data Analytics. Springer.

Rachman, F.F., dan Pramana, S. 2020. Analisis Sentimen Pro Dan Kontra Masyarakat Indonesia Tentang Vaksin Covid-19 Pada Media Sosial Twitter. Indonesian of Health Information Management Journal. Vol.8, No.2, Desember 2020, p.100109.

Sarkar, D. 2016. Text Analytics with Python : A Practical Real-World Approach to Gaining Actionable Insights from your Data. Apress.

Sebei, H., 2018. Review of social media analytics process and Big Data pipeline. Springer.

Stieglitz, S., Mirbabaie, M., Ross, B., and Neuberger, C. 2017. Social Media Analytics - Challenges In Topic Discovery, Data Collection, And Data Preparation. Elsevier. International Journal of Information Management.

Syarifuddin, M. 2020. Analisis Sentimen Opini Publik Mengenai Covid-19 Pada Twitter Menggunakan Metode Naïve Bayes Dan Knn. Inti Nusa Mandiri, Vol. 15, No. 1, pp. 23-28, 2020. 
JUSTINDO (Jurnal Sistem \& Teknologi Informasi Indonesia), Vol. 6, No. 2, Agustus 2021

Szabo, G., dkk., 2019. Social Media Data Mining and Analytics. John Wiley \& Sons, Inc. 